\title{
Knowledge, Attitude, and Practice of Mothers regarding Oral Hygiene of Primary School children in Chennai, Tamil Nadu, India
}

\author{
1Deepa Gurunathan, ${ }^{2}$ Joyson Moses, ${ }^{3}$ Shanmugaavel K Arunachalam
}

\begin{abstract}
Introduction: Children depend on their parents and caretakers for maintenance of their oral health. Parents play a major role in both preventive and treatment regime in these children. This study was conducted with the aim of evaluating the influence of parental education on knowledge, attitude, and practice of mothers regarding oral health of primary schoolchildren in Chennai.
\end{abstract}

Materials and methods: A 15-item self-administered questionnaire was used among 465 parents of preschool children in Chennai, of which 432 mothers returned the filled questionnaire. The data collected were subjected to statistical analysis using frequency of responses and chi-square test $(p<0.01)$. Data were analyzed using statistical package.

Results: Of the 432 mothers who participated in the study, $150(35 \%)$ have studied up to school level and $282(65 \%)$ have completed diploma/degree. The knowledge of mothers regarding the knowledge of importance of oral health for general health is appreciable, but the awareness of proper brushing habit, treatment of caries, and importance of dental visits is less in mothers who have school education when compared with graduate mothers.

Conclusion: Mothers who are graduates are more aware of the importance of oral health in children, treatment of dental caries, and brushing technique than mothers with school education. Hence, it is essential that government and health care providers impart oral health knowledge to mothers, as they are the role-models for their children.

Keywords: Attitude, Knowledge, Mothers, Practice, Primary schoolchildren.

How to cite this article: Gurunathan D, Moses J, Arunachalam SK. Knowledge, Attitude, and Practice of Mothers regarding Oral Hygiene of Primary School children in Chennai, Tamil Nadu, India. Int J Clin Pediatr Dent 2018;11(4):338-343.

\footnotetext{
${ }^{1,2}$ Professor, ${ }^{3}$ Senior Lecturer

${ }^{1,3}$ Department of Pedodontics, Saveetha Dental College Saveetha Institute of Medical and Technical Science, Saveetha University, Chennai, Tamil Nadu, India

${ }^{2}$ Department of Pedodontics, Thai Moogambigai Dental College Chennai, Tamil Nadu, India
}

Corresponding Author: Deepa Gurunathan, Professor Department of Pedodontics, Saveetha Dental College Saveetha Institute of Medical and Technical Science, Saveetha University Chennai, Tamil Nadu, India, Phone: +914426154170, e-mail: drgdeepa@yahoo.co.in

\section{Source of support: Nil}

Conflict of interest: None

\section{INTRODUCTION}

Parent's belief toward children's oral health plays an important consideration to improve children's oral health. In spite of the fact that early childhood caries (ECC) has been widely studied and preventive programs implemented in certain countries, ${ }^{1}$ ECC is more commonly seen in socially disadvantaged groups, who are devoid of health care systems. ${ }^{2}$ Early childhood caries continues to be a social health problem in countries like in India where there is no national program of oral health assessment and primary oral health care.

In order to achieve the best oral health outcomes in children, parents are key persons in ensuring the wellbeing of young children. ${ }^{3}$ A number of risk factors are associated with ECC, which can be broadly classified into biological and social risk factors. ${ }^{4}$ Social risk factors comprise low parental education, low socioeconomic status, and lack of awareness about the dental disease. ${ }^{5}$ To maintain a good oral hygiene, both the parent and the child must work together. It is seen that poor attitude of parents generally reflect as a poor oral health in children and vice versa. ${ }^{6}$ The need to commence prevention at a very young age and that the best chance of reducing further inequalities in health relate to parents and in particular to mothers and children. Parents' perceptions of their children's oral health as being better than their own should not be mistaken for the children's oral health status as being good. ${ }^{2}$ Hence, it is essential to assess the knowledge, attitude. and practices about their children's oral health which will help the health providers to understand the reasons for development of oral diseases in children and failure to get them treated.

\section{MATERIALS AND METHODS}

The subjects of this study were selected randomly from a public school, SBOA Matriculation School. A total of 465 students were selected for this study and each of them was provided with a questionnaire for the study, and each of the questionnaire contained 15 questions. Subjects were parents of children from classes 1 to 5 . 
Approval from the directorate of education was obtained, and a letter was sent to the selected school explaining the purpose of this study and the procedures that would be followed during its conduct. The principal of the school was asked to inform the students and their parents about the study, and a day was set for distributing and collecting the data.

The questionnaire was divided into three categories. The dental attitude, knowledge, and practice of mothers regarding their children's oral health were assigned in each division.

\section{RESULTS}

A total of 465 students belonging from classes 1 to 5 were selected randomly and their mothers were asked to answer the questionnaire. Out of 465 students, 432 returned completed questionnaires with a response rate of $97.7 \%$. Out of these, mothers who have completed school were $34.72 \%$ and mothers who have completed diploma/ degree were $65.28 \%$. Of the students, $57 \%$ were males and $43 \%$ were females. Of the total population, mothers who have done only schooling were 150 (35\%) and who have completed diploma/degree were 282 (65\%).

\section{Knowledge of Mothers regarding Oral Health of Children}

Various questions regarding the oral health knowledge, such as how important healthy teeth are for general health, reasons for brushing teeth, how often should children have dental check-up were asked; $96.0 \%$ of mothers who completed school accepted that healthy teeth are important for general health and $4 \%$ did not even know how important healthy teeth are for general health. Among the mothers who completed diploma/degree, $96.8 \%$ agreed and $2.1 \%$ were unaware that healthy teeth are important for general health (Table 1).

In all, $43.9 \%$ of mothers who completed school stated cleaning as a reason for brushing teeth, $42.1 \%$ for caries prevention, and $14.0 \%$ stated that brushing is done to prevent foul breath. Cleaning (48.9\%) was the major reason stated by the mothers who completed diploma/ degree; $44.7 \%$ suggested that brushing is done for caries

Table 1: Knowledge of mothers regarding oral health of children

\begin{tabular}{|c|c|c|c|c|}
\hline \multirow[b]{2}{*}{ Questions } & & \multicolumn{2}{|c|}{ Graduation } & \multirow[b]{2}{*}{$p$-value* } \\
\hline & & School & Diploma/graduate & \\
\hline \multirow[t]{3}{*}{ Healthy teeth are very important for general health } & Agree & 48 & 91 & 0.623 \\
\hline & Disagree & 0 & 1 & \\
\hline & Don't know & 2 & 2 & \\
\hline \multirow[t]{3}{*}{ It is possible to prevent the teeth loss due to caries } & Agree & 32 & 71 & 0.328 \\
\hline & Disagree & 7 & 10 & \\
\hline & Don't know & 11 & 13 & \\
\hline \multirow[t]{3}{*}{ Children's teeth should be checked regularly by dentist } & Agree & 40 & 77 & 0.534 \\
\hline & Disagree & 5 & 12 & \\
\hline & Don't know & 5 & 5 & \\
\hline \multirow[t]{3}{*}{ If yes once in every } & 3 months & 30 & 26 & $0.009^{*}$ \\
\hline & 6 months & 17 & 42 & \\
\hline & 12 months & 10 & 26 & \\
\hline \multirow[t]{3}{*}{ Reasons for brushing teeth } & Bright teeth & 25 & 46 & 0.288 \\
\hline & Prevent decay & 24 & 42 & \\
\hline & Foul breath & 8 & 6 & \\
\hline \multirow[t]{3}{*}{ What are the main sources of dental health information? } & Dentist & 32 & 74 & 0.037 \\
\hline & Physician & 1 & 5 & \\
\hline & Media & 7 & 15 & \\
\hline \multirow[t]{3}{*}{ Bacteria and sugar can cause tooth decay } & Agree & 42 & 83 & 0.769 \\
\hline & Disagree & 2 & 2 & \\
\hline & Don't know & 4 & 9 & \\
\hline \multirow[t]{3}{*}{ Bacteria and dental plaque cause gingival bleeding } & Agree & 34 & 64 & 0.909 \\
\hline & Disagree & 3 & 4 & \\
\hline & Don't know & 14 & 26 & \\
\hline \multirow[t]{5}{*}{ Preventive measures of dental diseases } & Toothbrushing & 35 & 70 & 0.064 \\
\hline & Fluoride toothpaste & 8 & 21 & \\
\hline & Floss & 3 & 3 & \\
\hline & $\begin{array}{l}\text { Pit and fissure } \\
\text { sealants }\end{array}$ & 2 & 0 & \\
\hline & Fluoride application & 2 & 0 & \\
\hline
\end{tabular}


prevention and $6.4 \%$ said that brushing was done to prevent foul breath.

A total of $80 \%$ of those who completed school agreed that children should have a regular dental check-up, 10\% disagreed with the same, and 10\% did not even have knowledge about it. And among the mothers who have completed diploma/degree, $81.9 \%$ agreed to it; 12.8 and $5.3 \%$ disagreed.

\section{Attitude of Parents regarding Oral Hygiene of Children}

The questionnaire was prepared to know the attitude of parent toward oral hygiene, and five question were given; $42 \%$ of mothers who have done schooling stated that they do not care if no pain in a decay tooth, 32\% said they would just try to cope with it, $20 \%$ would see the dentist. While $85 \%$ of mothers who completed diploma/degree said that they would see the dentist (Table 2).

A significant difference was seen with respect to the attitude of the parents whose education was diploma and schooling. Parents who were graduated or held diploma felt that it is necessary to teach the children brushing and take the children to dentist if they have signs of tooth decay. Also most of the graduate parents (46.8\%) have reported rolling as the method of toothbrushing.

No significant difference was seen among the interval of exchange of toothbrush and the frequency of dental visits.

\section{Practice of Mothers regarding Oral Hygiene of Children}

Among the day-to-day practices, parents with diploma or graduation (40\%) checked regularly their child's teeth after toothbrushing than the parents who have done only schooling. No significant difference was seen among the parents of diploma and school graduated among the frequency, occasion, and time spent on toothbrushing (Table 3).

\section{DISCUSSION}

The study was done to evaluate the influence of parental education on knowledge, attitude, and practice of caretakers regarding the oral health of children. Parents are the role-models for their children, and the habits adopted during childhood when the child is totally dependent on the mother are powerful means of establishing a novel behavior in children, such as that of toothbrushing. ${ }^{7,8}$ Hence, parents themselves have to have a good knowledge and attitude toward oral health in order to instill good oral habits in their children. ${ }^{9,10}$ In addition, the good knowledge and attitude must translate into good oral hygiene and dietary practices in order to have beneficial effects on dental health. ${ }^{11}$

Parental knowledge about infant oral health was found to be lacking in many studies. ${ }^{12,13}$ It was seen in the present study that education of parents plays a vital role regarding the attitude, knowledge, and practice of oral health in their children. A significant difference was seen among the response of educated and uneducated parents in regard to brushing habit, reason for gingival bleeding, and measures taken in order to treat dental problems. Hence, mothers with higher education have good knowledge, attitude, and practice about the oral health of children, which is similar to studies done in Kuwait. ${ }^{14}$

Table 2: Knowledge of mothers regarding oral health of children

\begin{tabular}{|c|c|c|c|c|}
\hline \multirow{2}{*}{ Questions } & & \multicolumn{2}{|r|}{ Graduation } & \multirow[b]{2}{*}{$p$-value * } \\
\hline & & School & Diploma/graduate & \\
\hline \multirow[t]{2}{*}{ It is necessary to teach children toothbrushing } & Agree & 32 & 85 & $<0.001^{*}$ \\
\hline & Disagree & 18 & 9 & \\
\hline \multirow[t]{3}{*}{ Till what age, children need help from adults in toothbrushing? } & 5 years & 26 & 36 & 0.274 \\
\hline & 10 years & 17 & 43 & \\
\hline & 15 years & 7 & 15 & \\
\hline \multirow[t]{4}{*}{ If having signs of tooth decay what do you do? } & Don't care & 21 & 9 & $<0.001^{*}$ \\
\hline & Try to cope up & 16 & 0 & \\
\hline & Visit dentist & 10 & 80 & \\
\hline & Brush teeth & 3 & 5 & \\
\hline \multirow[t]{2}{*}{ Frequency of visiting dentist } & 6 months & 23 & 41 & 0.143 \\
\hline & 12 months & 10 & 34 & \\
\hline \multirow[t]{3}{*}{ Method of brushing } & Horizontal & 27 & 20 & $<0.001^{*}$ \\
\hline & Vertical & 11 & 30 & \\
\hline & Rolling & 12 & 44 & \\
\hline \multirow[t]{3}{*}{ Interval of exchange of toothbrush } & Less than a year & 40 & 69 & 0.347 \\
\hline & More than a year & 6 & 20 & \\
\hline & Don't know & 4 & 5 & \\
\hline
\end{tabular}

${ }^{*} p<0.05$ 
Knowledge, Attitude, and Practice of Mothers regarding Oral Hygiene

Table 3: Practice of mothers regarding oral health of children

\begin{tabular}{|c|c|c|c|c|c|}
\hline \multirow[b]{2}{*}{ Questions } & & \multirow{2}{*}{$\begin{array}{l}\text { Knowledge/attitude/ } \\
\text { practice }\end{array}$} & \multicolumn{2}{|c|}{ Graduation } & \multirow[b]{2}{*}{$p$-value* } \\
\hline & & & School & Diploma & \\
\hline \multirow[t]{2}{*}{ Frequency of toothbrushing } & Once daily & Practice & 20 & 32 & 0.479 \\
\hline & Twice daily & & 30 & 62 & \\
\hline \multirow[t]{3}{*}{ Occasion of toothbrushing } & Morning & Practice & 34 & 63 & 0.865 \\
\hline & Evening after meals & & 8 & 13 & \\
\hline & Evening after sweets & & 8 & 18 & \\
\hline \multirow[t]{3}{*}{ I check my child's teeth after brushing } & Regularly & Practice & 25 & 40 & $0.026^{*}$ \\
\hline & Sometimes & & 8 & 42 & \\
\hline & Never & & 7 & 12 & \\
\hline \multirow[t]{2}{*}{ Time spent on brushing teeth } & $<3$ minutes & Practice & 29 & 50 & 0.581 \\
\hline & $>3$ minutes & & 21 & 44 & \\
\hline \multirow{4}{*}{$\begin{array}{l}\text { Dental visits for the child within the past } \\
12 \text { months }\end{array}$} & Once & Practice & 17 & 42 & 0.235 \\
\hline & Twice & & 7 & 18 & \\
\hline & Thrice & & 5 & 10 & \\
\hline & Never & & 21 & 24 & \\
\hline
\end{tabular}

* $p$-value calculated using chi-square test; $p<0.05$ is statistically significant

Though there was no statistically significant difference between the two groups regarding the knowledge of healthy teeth toward general health, the graduate mothers were more concerned about the oral health, which is similar to previous studies. ${ }^{14,15}$ It is difficult to employ effective disease preventive strategies without basic knowledge of caries risk factor and oral maintenance. ${ }^{16}$ Majority of the parents had knowledge that sweetened food substances cause caries. The findings of the present study were similar to findings of Suresh et $\mathrm{al}_{1}{ }^{16}$ Lin et $\mathrm{al}_{1}{ }^{17}$ and Kumar et $\mathrm{al}_{1}{ }^{18}$ who also reported that parents of preschoolchildren had good knowledge about dietary process.

In spite of a substantial number of participants being aware that preventive measures can prevent dental diseases, there are shortcomings in the area of preventive practices. The school literate mothers did not give importance to brushing of teeth which is the basic preventive tool. The results are in agreement with the study by al-Tamimi and Petersen ${ }^{19}$ who reported a diffuse oral health knowledge and positive attitude of mothers toward prevention and participation in oral health education of children. A study by Hood et $\mathrm{al}^{11}$ in the United Kingdom also showed similar results where parents were well informed about the causes of caries, but were less sure of preventive methods. In the present study, others are aware of preventive measures, such as fluoride, floss, and sealants, but the extent to which these tools are used is questionable.

Parisotto et $\mathrm{al}^{20}$ showed that the higher the levels of maternal salivary mutans streptococci (MS), the greater the risk of transmission of MS to their infant. Apart from MS salivary levels, the mother's oral hygiene, snack frequency, periodontal disease, and socioeconomic status are also associated with infant colonization. ${ }^{21}$ Toothbrushing is an effective tool in maintaining the oral hygiene and prevention of caries. In the present study, importance of brushing was underestimated by parents who had only school education when compared with graduates which is also seen in studies done by Astrom ${ }^{22}$ and Vallejos-Sanchez et al. ${ }^{23}$ However, most of the mothers felt that brushing helps to have clean teeth and to prevent caries. Hence, the mothers do understand the advantage for brushing, but not able to appreciate the importance of daily brushing. Most of the mothers agreed that till 5 years, brushing of children needed to be supervised which is similar to a study done in Mangaluru. ${ }^{24}$ Mothers with higher education felt that it is necessary to teach children toothbrushing and check the teeth after children brushed their teeth. This could motivate the children to do better brushing and to maintain the oral hygiene.

In addition, mothers with lesser education are not aware of the reason for bleeding gums. Hence, parents with only school education might not understand the importance of brushing. This can lead to reduced frequency in brushing in children which is not reflected in the study. However, Martins et $\mathrm{al}^{25}$ have reported that there is a difference between reported toothbrushings. This is supported by the observation in our study that even if mothers say that the children brush twice daily, when probed the occasion of brushing, they have responded as brushing was done only in the morning. Most of the participants in the study knew that the child's brushing should have been supervised till the age of 5 years; however, over half the parents in rural Victoria Gussy were of the opinion that children were capable of brushing their own teeth by the age of 4 years. In another 
study by Vaitkeviciene et al, ${ }^{26}$ a very low percentage of parents guided and brushed their children's teeth.

Mothers with higher education in this study knew about the rolling and vertical method of brushing unlike school-educated mothers. This proves that mothers with higher education are accessible to information regarding oral hygiene which is in accordance with a study done in Norway. ${ }^{22}$

In the present study, there was no statistically significant difference between parents with higher education and those with school education. However, although many parents reported taking their children to the dentist every 6 months, most respondents only take their children to the dentist when a problem arises, which is similar to a study done in Brazil. ${ }^{27}$

It has been observed in this study that most of graduated mothers derive knowledge regarding oral health of their children from the dentists which is similar to findings in a study done in Brazil. ${ }^{27}$ Mothers who visit the dentist often may acquire more knowledge regarding the oral care of children. ${ }^{28}$

Thus, it can be concluded form this study that mothers who have school education are not much aware of the preventive measures of dental disease, importance of toothbrushing, and dental visits. Hence, it is the responsibility of the government and health care providers to impart oral health knowledge to mothers, as they are the role-models for their children.

\section{REFERENCES}

1. Pitts NB, Palmer JD. The dental caries experience of 5-, 12- and 14-year-old children in Great Britain. Surveys coordinated by the British Association for the Study of Community Dentistry in 1991/92, 1992/93, and 1990/91. Comm Dent Health 1994;11(1):42-52.

2. Acheson D. Inequalities in health. Report on inequalities in health did give priority for steps to be tackled. BMJ 1998 Dec;317(7173):1659.

3. Inglehart, MR.; Filstrup, SL.; Wandera, A. Oral health and quality of life in children. In: Inglehart MR, Bagramian R, editors. Oral health-related quality of life. Chicago (IL): Quintessence; 2002. pp. 79-88,

4. Berg, JH.; Slayton, RL.; editors. Early childhood oral health. Singapore: Wiley-Blackwell; 2009.

5. Hallett KB, $\mathrm{O}^{\prime}$ Rourke PK. Social and behavioural determinants of early childhood caries. Aust Dent J 2003 Mar;48(1):27-33.

6. Hinds, K.; Gregory, JR. National diet and nutrition survey: children aged $11 / 2$ to $4 \frac{1}{2}$ years. Report of dental survey. Vol. 2. London: HMSO; 1995.

7. Okada M, Kawamura M, Miura K. Influence of oral health attitude of mothers on the gingival health of their school age children. ASDC J Dent Child 2001 Sep-Dec;68(5-6): 379-383, 303.

8. Szatko F, Wierzbicka M, Dybizbanska E, Struzycka I, IwanickaFrankowska E. Oral health of Polish three-year-olds and mothers' oral health-related knowledge. Community Dent Health 2004 Jun;21(2):175-180.
9. Grytten J, Rossow I, Steele L. Aspects of the formation of dental health behaviours in early childhood. Dent Health 1989 Aug;28(4):6, 8-10.

10. Blinkhorn AS. Influence of social norms on toothbrushing behavior of preschool children. Community Dent Oral Epidemiol 1978 Sep;6(5):222-226.

11. Hood CA, Hunter ML, Kingdon A. Demographic characteristics, oral health knowledge and practices of mothers of children aged 5 years and under referred for extraction of teeth under general anesthesia. Int J Paediatr Dent 1998 Jun;8(2):131-136.

12. Gussy MG, Waters EB, Riggs EM, Lo SK, Kilpatrick NM. Parental knowledge, beliefs and behaviours for oral health of toddlers residing in rural Victoria. Aust Dent J 2008 Mar;53(1): 52-60.

13. Blinkhorn AS, Wainwright-Stringer YM, Holloway PJ. Dental health knowledge and attitudes of regularly attending mothers of high-risk, pre-school children. Int Dent J 2001 Dec;51(6):435-438.

14. Ashkanani F, Al-Sane M. Knowledge, attitudes and practices of caregivers in relation to oral health of preschool children. Med Princ Pract 2013;22(2):167-172.

15. Williams NJ, Whittle JG, Gatrell AC. The relationship between socio-demographic characteristics and dental health knowledge and attitudes of parents with young children. Br Dent J 2002 Dec;193(11):651-654.

16. Suresh BS, Ravishankar TL, Chaitra TR, Mohapatra AK, Gupta V. Mother's knowledge about pre-school child's oral health. J Indian Soc Pedod Prev Dent 2010 Oct-Dec;28(4): 282-287.

17. Lin HC, Wong MC, Wang ZJ, Lo EC. Oral health knowledge, attitudes, and processes of Chinese adults. J Dent Res 2001 May;80(5):1466-1470.

18. Kumar RP, John J, Saravanan S, Arumugham IM. Oral health knowledge, attitude and process of parents and their attendants visiting College of Dental Surgery, Saveetha University, Chennai. J Indian Assoc Public Health Dent 2009 Jan;7(13): 43-53.

19. al-Tamimi S, Petersen PE. Oral health situation of schoolchildren, mothers and schoolteachers in Saudi Arabia. Int Dent J 1998 Jun;48(3):180-186.

20. Parisotto TM, Steiner-Oliveira C, Silva CM, Rodrigues LK, Nobre-dos-Santos M. Early childhood caries and mutans streptococci: a systematic review. Oral Health Prev Dent 2010 Jan;8(1):59-70.

21. Wan AK, Seow WK, Purdie DM, Bird PS, Walsh LJ, Tudehope DI. Oral colonization of Streptococcus mutans in six-month-old predentate infants. J Dent Res 2001 Dec;80(12): 2060-2065.

22. Astrom AN. Parental influences on adolescents' oral health behavior: two-year follow-up of the Norwegian Longitudinal Health Behavior Study participants. Eur J Oral Sci 1998 Oct;106(5):922-930.

23. Vallejos-Sanchez AA, Medina-Solís CE, Maupome G, CasanovaRosado JF, Minaya-Sanchez M, Villalobos-Rodelo JJ, Pontigo-Loyola AP. Sociobehavioral factors influencing tooth brushing frequency among school children. J Am Dent Assoc 2008 Jun;139(6):743-749.

24. Pullishery F, Panchmal GS, Shenoy R. Parental attitudes and tooth brushing habits in preschool children in Mangalore, Karnataka: a cross-sectional study. Int J Clin Pediatr Dent 2013 Dec;6(3):156-160. 
25. Carolina Martins CC, Oliveira MJ, Pordeus IA, Paiva SM. Comparison between observed children's tooth brushing habits and those reported by mothers. BMC Oral Health 2011 Sep;11:22.

26. Vaitkeviciene V, Milciuviene S, Zaborskis A. Oral hygiene of preschool children in Kaunas city and their parents' attitude towards children's oral health. Medicina (Kaunas) 2005 Feb;41(5):427-434.
27. FernandaTrindade FA, Valente AR, Andrade MR, Tannure PN, Antonio AG, da Silva Fidalgo TK. Knowledge and practices of parents and guardians regarding the oral health of children from a shelter and a University in Rio de Janeiro, Brazil. Brazil Res Pediatr Dent Integr Clin 2014 Dec;14(4):293-302.

28. Silver DH. A comparison of 3-year-olds' caries experience in 1973, 1981 and 1989 in a Hertfordshire town, related to family behaviour and social class. Br Dent J 1992 Mar;172(5):191-197. 